\title{
KOMUNIKASI GURU PENDIDIKAN AGAMA DALAM MEMBENTUK KARAKTER SISWA
}

\author{
Heri Rahmatsyah Putra ${ }^{1}$, Fadhlur Rahman Armi \\ ${ }^{1,2}$ Sekolah Tinggi Agama Islam Negeri Teungku Dirundeng Meulaboh \\ Email Kontributor: herirahmatsyahputra@staindirundeng.ac.id
}

\begin{abstract}
Abstrak
Karakter merupakan modal penting dalam kehidupan manusia. Karakter dibentuk pada lingkungan keluarga dan sekolah. Sekolah sebagai lembaga tempat menimba ilmu dan menemukan jati diri bagi siswa ditentukan oleh kemampuan komunikasi guru pendidikan agama dalam mempengaruhi dan memberikan tunjuk ajar serta contoh yang baik kepada siswa. Penelitian ini dilakukan dengan menggunakan metode field research melalui pendekatan kualitatif. Hasil dari penelitian menunjukkan bahwa guru pendidikan agama telah memberikan pemahaman dan pengaruh terhadap pembentukan karakter siswa melalui peran penting guru dan kemampuan guru untuk mengelola interaksi dalam kegiatan pembelajaran melalui komunikasi yang baik untuk mengembangkan sikap positif melalui penanaman nilai-nilai keislaman agar siswa dapat menumbuhkan rasa percaya diri. Melalui kemampuan guru untuk bersikap terbuka, sensitif, responsif, ramah dan sabar kepada siswa dalam pembelajaran. Serta dengan kemampuan guru untuk mengembangkan sikap positif dalam kegiatan pembelajaran.
\end{abstract}

Kata kunci: Komunikasi, Guru Agama, Karakter

\begin{abstract}
Character is an important capital in human life. Character is formed in the family and school environment. Schools as institutions for gaining knowledge and finding identity for students are determined by the communication skills of religious education teachers in influencing and providing instruction and good examples to students. This research was conducted using the field research method through a qualitative approach. The results of the study indicate that religious education teachers have provided understanding and influence on the formation of students' character through the important role of teachers and the ability of teachers to manage interactions in learning activities through good communication to develop positive attitudes through inculcating Islamic values so that students can grow a sense of trust. self. Through the ability of teachers to be open, sensitive, responsive, friendly and patient to students in learning. As well as with the ability of teachers to develop a positive attitude in learning activities.
\end{abstract}

Keyword: Communication, Teacher of Religion, Character 


\section{A. PENDAHULUAN}

Manusia merupakan makhluk ciptaan tuhan yang diciptakan dengan berbagai perbedaan pada jiwa dan raganya. Salah satu yang unsur pembeda pada diri manusia ada pada karakter yang dimiliki. Karakter merupakan cara berpikir dan berperilaku yang menjadi ciri khas tiap individu untuk hidup dan berkerjasama, baik dalam lingkup keluarga, masyarakat, bangsa dan negara. Karakter adalah sifat, psikologi, pikiran, dan perilaku seseorang yang membedakannya dengan orang lain. Oleh karena itu, orang yang berperilaku tidak jujur, kejam atau serakah disebut orang yang berkarakter buruk, dan orang yang berperilaku jujur dan suka menolong disebut orang yang berkarakter baik. (Elisah, 2011)

Bagi individu yang memiliki kesuksesan, karakter yang baik menjadi salah satu modal penting. Setiap orang harus memupuk budi pekerti yang baik, apapun yang terjadi, ia berada di koridor kebenaran. Perjalanan hidup menunjukkan bahwa hanya orang-orang yang bermoral tinggi yang dapat bertahan dalam masa-masa sulit. Setiap anak manusia yang lahir diharapkan memiliki karakter yang baik. Untuk menumbuhkan karakter yang kuat dan jiwa yang baik pada anak-anak di rumah, perlu diciptakan lingkungan keluarga yang harmonis dan energik. Jika komunikasi dua arah yang kuat terjalin antara orang tua dan anak, hal ini dapat tercipta. Tujuan pelatihan karakter pada dasarnya adalah untuk mendorong lahirnya anak-anak yang baik. Dengan tumbuh dan berkembangnya karakter yang baik, anak akan terpacu untuk berjanji melakukan hal-hal yang terbaik, mengerjakan segala sesuatu dengan baik, dan tumbuh dalam kemampuan untuk memiliki tujuan hidup.

Peran masyarakat juga sangat penting dalam membentuk karakter anak melalui orang tua dan lingkungan. Begitu peran pendidikan juga tidak kalah pentingnya dalam pembentukan karakter anak. Seorang anak manusia yang dilahirkan ke dunia pasti akan mengalami fase pendewasaan dalam hidup. Dimulai dari lingkungan terkecil yaitu keluarga, kemudian ke lingkungan yang lebih besar yaitu sekolah. Guru sebagai pendidik merupakan profesi yang mulia dalam kehidupan manusia, dalam Islam juga dijelaskan mengenai peran guru. Tidak akan ada peradaban tanpa keberadaan sosok guru.

Dari perspektif proses ini, pendidikan adalah komunikasi, yaitu proses ini melibatkan dua komponen yang terdiri dari orang-orang tertentu, yaitu pendidik sebagai komunikator dan peserta didik sebagai komunikan. Pada tingkat menengah ke bawah, pendidik itu sendiri disebut guru dan peserta didik itu sendiri adalah siswa. Perbedaan antara komunikasi dan pendidikan terletak pada tujuan dan efek yang diharapkan. Dilihat dari efek yang diharapkan, tujuan komunikasi bersifat umum, tetapi tujuan pendidikan bersifat khusus. Dalam perjalanan tahapan dari proses komunikasi, kekhususan ini memunculkan istilah-istilah khusus: informasi, publisitas, indoktrinisasi, dan sebagainya (Onong Uchjana Effendy, 2007). Komunikasi merupakan aktivitas dasar dari seluruh interaksi antar manusia, karena tanpa komunikasi interaksi antar manusia baik perseorangan maupun kelompok tidak akan pernah terjadi. Komunikasi memainkan peran penting dalam kehidupan manusia, hampir setiap saat manusia bertindak dan belajar dengan melalui komunikasi karena komunikasi memain peran yang dominan salah satunya hubungan manusia dalam mencapai saling pengertian (Putra, 2021).

Komunikasi dalam pembelajaran yang efektif akan memudahkan siswa menerima informasi dari guru. Kegiatan belajar mengajar antara pendidik dam peserta didik merupakan wujud dari bagaimana proses pendidikan secara langsung dalam sebuah satuan pendidikan. 
Dengan terciptanya kualitas dalam proses belajar mengajar, maka akan berpengaruh dengan terciptanya kualitas pendidikan yang menghasilkan sumber daya manusia. Oleh karena itu dalam proses belajar mengajar membutuhkan sarana komunikasi agar apa yang disampaikan dalam pembelajaran bisa tecerna dan mampu dipahami (Zakaria, 2021).

Bentuk komunikasi guru pendidikan agama dapat membentuk karakter kedisiplinan di sekolah dengan memberikan pengarahan mengenai tata tertib yang ada di sekolah, yang di dalamnya terdapat tata tertib tentang kedisiplinan agar para siswa memahami makna kedisiplinan itu sendiri. Penerapan komunikasi yang baik diajarkan dalam agama Islam dengan menggunakan kata-kata yang baik. Begitupun dengan isi pesan yang disampaikan, sebagai seorang guru pendidikan agama tentu harus dapat mengajarkan mengenai karakter yang harus dimiliki oleh siswa. Islam mengajarkan manusia untuk berpakaian rapi dan bersih, yang merupakan salah satu upaya yang dapat dikomunikasikan kepada peserta didik untuk menjaga kedisiplinan dalam berpakaian. Begitu pula ketika ada proses pembelajaran di dalam kelas, jika ada siswa yang ribut dan tidak memperhatikan guru saat menjelaskan akan ditegur tanpa mengabaikan nilai-nilai pendidikan dalam teguran tersebut. Beberapa siswa akan ditegur dan ditanyai oleh guru ketika mereka meninggalkan kelas sebelum jam istirahat. Melalui sanksi atau hukuman tersebut di atas, diharapkan selain membudayakan karakter siswa yang baik juga akan memberikan efek jera bagi siswa.

Dalam melakukan penelitian ini, penulis membaca kajian terdahulu yang relevan yaitu penelitian milik Tarmizi skripsinya berjudul "Komunikasi Guru Agama dalam Membentuk Karakter Siswa/I Di SMPN 02 Rambah Hilir”. Dalam penelitiannya Tarmizi ingin mengetahui bagaimana komunikasi guru agama dalam membentuk karakteristik siswanya. Adapun jenis penelitiannya adalah deskriptif kualitatif dengan menggunakan kedalaman data. Hasil dari penelitian Tarmizi adalah bahwa komunikasi yang dilakukan oleh guru agama dalam mebentuk karakteristik siswa yaitu dengan menerapkan kedisiplinan (Tarmizi, 2000). Terdapat persamaan dan perbedaan dalam penelitian ini yaitu sama-sama ingin mengetahui komunikasi guru agama dalam membentuk karakter siswa. Adapun perbedaannya yaitu Tarmizi melakukan penelitian di SMPN 02 Rambah Hilir, sedangkan penulis melakukan penelitian di SMAN 1 Bangko Kabupaten Rokan Hilir.

Kemudian pada penelitian Nur Ainiyah, Nazar Husain Hadi Pranata Wibawa menegaskan Penanaman karakter pada anak sejak dini berarti ikut mempersiapkan generasi bangsa yang berkarakter, mereka adalah calon generasi bangsa yang diharapkan mampu memimpin bangsa dan menjadikan negara yang berperadaban, menjunjung tinggi nilai-nilai luhur bangsa dengan akhlak dan budi pekerti yang baik serta menjadi generasi yang berilmu pengetahuan tinggi dan menghiasi dirinya dengan iman dan taqwa. Oleh karena itu pembelajaran pendidikan agama Islam (PAI) di sekolah sebagai salah satu upaya pembentukan karakter siswa sangatlah penting. Pembentukan Karakter anak akan lebih baik jika muncul dari kesadaran keberagamaan bukan hanya karena sekedar berdasarkan prilaku yang membudaya dalam masyarakat (Ainiyah \& Wibawa, 2013).

Penelitian Anton Susanto menunjukkan pola komunikasi yang digunakan oleh guru agama dalam pembinaan akhlak siswa SMK Al-Fajar Kasui Way Kanan adalah komunikasi kelompok kecil indikasi ini dilihat dari guru agama menyampaikan kepada siswa dan didengarkan dengan seksama pesan yang disampaikan oleh guru Agama. Dalam hal tersebut timbulah feedback atau umpan balik dari siswa-siswi. Dalam peleksanaan penyampaiannya terdapat pola komunikasi yang 
efektif ini dilihat dari seorang guru uang sudah menyiapakan rencana program pembelajaran yang sesuai dengan kurikulum pendidikan yang digunakan. Pola komunikasi yang digunakan oleh guru agama Islam dalam pembinaan akhlak, sudah tercipta dengan baik karna bisa dilihat dari yingkat kedisiplinan dan tanggung jawab mereka yang sudah menerapkan akhlak yang baik di lingkungan sekolah. Dan juga di dukung dengan kegiatan atau program-progaram yang mendukung dalam pembinaan akhlak (Kanan, 2017).

\section{B. METODE PENELITIAN}

Penelitian ini merupakan penelitian deskriptif kualitatif yang bertujuan menjelaskan fenomena melalui pengumpulan data yang sedalamnya mengenai bentuk komunikasi guru pendidikan agama Islam dalam membentuk karakter siswa di SMAN 1 Bangko Rokan Hilir, Riau. Penelitian ini dilaksanakan bulan November 2020. Teknik pengumpulan data pada penelitian ini menggunakan metode pengamatan sementara (observasi), wawancara langsung maupun tidak langsung kepada guru yang mengajarkan mata pelajaran agama, serta data pendukung dokumentasi. Dalam penelitian yang menjadi informan penelitian merupakan guru pendidikan agama sejumlah 10 orang. Setelah mengumpulkan data peneliti menggunakan model analisis data interaktif Huberman dan Miles (Danim, 2002) yakni tahapan analisis data dengan mereduksi data, proses reduksi data diartikan sebagai proses pemilihan, pemusatan perhatian pada penyederhanaan, pengabstrakan, dan transformasi data "kasar" yang muncul dari catatan-catatan yang tertulis di lapangan. Penyajian data dengan mengelompokkan sekumpulan informasi yang diperoleh secara tersusun dan memberikan kemungkinan adanya penarikan kesimpulan dan pengambilan tindakan. Penarikan kesimpulan, penulis mengimplementasikan prinsip induktif dengan mempertimbangkan pola-pola data yang ada dan atau kecenderungan dari data yang dibuat. Jadi penulis dapat memaparkan kesimpulan dari sudut pandang penulis untuk lebih mempertegas penelitian.

\section{HASIL DAN PEMBAHASAN}

Istilah karakter dihubungkan dan dipertukarkan dengan istilah etika, ahlak, dan atau nilai dan berkaitan dengan kekuatan moral, berkonotasi "positif" bukan netral. Oleh karena itu Pendidikan karakter secara lebih luas dapat diartikan sebagai pendidikan yang mengembangkan nilai budaya dan karakter bangsa pada diri peserta didik sehingga mereka memiliki nilai dan karakter sebagai karakter dirinya, menerapkan nilai-nilai tersebut dalam kehidupan dirinya sebagai anggota masyarakat, dan warga negara yang religius, nasionalis, produktif, dan kreatif (Ainiyah \& Wibawa, 2013). Komunikasi dalam dunia pendidikan, khususnya dalam proses belajar mengajar merupakan hal yang sangat esensial, bahkan dapat dikatakan bahwa komunikasi merupakan ruh utama dalam dunia pendidikan. Bagaimana tidak, dalam proses belajar mengajar, penyampaian materi pembelajaran di kelas secara umum dilakukan oleh guru melalui komunikasi atau sesuatu yang dibicarakan oleh guru atau transfer ilmu memalui bahasa. Keberhasilan transfer ilmu dari guru kepada siswa terletak pada kemampuan guru dalam membahasakan materi-materi pelajaran. Guru yang baik dituntut agar mampu mengkomunikasikan materi pelajaran secara sederhana agar mudah dipahami oleh siswa (Zakaria, 2021).

Guru agama atau pendidik merupakan profesi yang secara implisit rela dan menerima serta memikul sebagian beban yang dipikul oleh orang tua siswa. Menjadi guru sejak dulu merupakan 
profesi yang sangat dihormati di tengah masyarakah, khususnya di negara-negara bagian timur. Jika diamati dari perspektif ilmu pendidikan Islam, seorang guru yang baik seharusnya memenuhi kriteria yang diperkirakan dapat dipertanggung jawabkan, seorang guru agama hendaknya senantiasa bertakwa kepada Allah, memiliki kesehatan rohani, berilmu, berakhlakul karimah, serta berjiwa nasionalis. Seiring perkembangan zaman, sekolah sebagai lembaga penyelenggara pendidikan seharusnya memiliki beberapa orang guru agama agar setiap siswa-siswinya mendapat pembinaan dan pembangunan kepribadian (karakter) yang baik sesuai ajaran agama. Guru agama seyogyanya mampu memberikan pengaruh atau menciptakan kesan positif kepada selurus siswa, baik secara sengaja, maupun hal-hal yang dilakukan secara tidak sengaja.

Guru agama seharusnya memiliki kesadaran dan kepekaan terhadap segala tingkah laku, gaya, sikap, serta penampilannya. Karena hal itu akan berdampak besar kepada siswa karena dapat menjadi teladan. Jadi, profesi guru jelaslah tidak sama dan sembarangan dibandingkan profesi lainnya. Pada satu waktu, seorang guru agama dapat menjadi da'i yang memberikan suri tauladan dan menjadi role model kepada mad' $u$ (siswa), tidak hanya bertanggung jawab dengan paham atau tidaknya terhadap penyampaian materi ajar guru tersebut, melainkan dapat membina secara nyata dan langsung serta mengarahkan siswa kepada yang baik dan menjauhjan diri dari hal-hal yang buruk dan dapat merusak masa depan. Hal seperti ini tentu saja berlaku bagi seluruh guru di sekolah, bukan hanya guru pendidikan agama semata (Dakwah et al., 2017b).

Dalam buku Pedoman Pelaksanaan Pendidikan Agama Islam (1986), diterangkan bahwa tugas dari guru agama meliputi:

a. Mengajar dan mendidik. Guru agama sekolah mengemban misi untuk mengajar dan mendidik siswa agar menjadi manusia yang beretika, dan misi guru agama adalah menjadi siswa yang berkepribadian Islami.

b. Sebagai seorang pendakwah. Guru agama sebagai da'i berarti guru agama perlu memberikan pesan yang baik agar memberikan pemahaman yang positif kepada guru dan siswa lain dan tidak mengganggu pengamalan pendidikan agama.

c. Sebagai pengasuh dan penyuluh. Oleh karena itu, guru agama harus peka terhadap sikap dan perilaku anak didiknya. Guru agama memiliki kewajiban untuk menumbuhkan semangat keagamaan anak didiknya dalam proses pembelajarannya, baik di sekolah maupun di luar. Hal ini menegaskan bahwa guru agama adalah pembangun mental dan spiritual.

d. Sebagai pemimpin informal. Kemampuan dan legal formal guru agama tidak hanya diterapkan dalam proses pembelajaran di depan kelas, tetapi juga gelar yang melekat di masyarakat, rumah dan lingkungan sosial. Guru agama dianggap sebagai pemuka agama lingkungan karena dianggap memiliki keahlian di bidang agama.

e. Guru agama perlu mendorong pertumbuhan iman. Pendidikan agama yang diselenggarakan di sekolah diharapkan dapat dikembangkan dengan menanamkan sikap cinta dan pengabdian kepada Allah SWT berdasarkan taqwa. Oleh karena itu, urusan utama yang terpenting adalah hubungan antara guru dan siswa.

f. Guru agama harus mendorong siswa untuk selalu bersyukur kepada Allah SWT. Guru agama berkewajiban untuk menstimulus, memupuk dan mengembangkan sikap cinta kasih kepada Allah SWT dengan memelihara dan memanfaatkan alam lingkungan yang 
merupakan karunia Allah SWT. Sikap baik yang ditanamkan ustadz kepada anak didiknya tidak akan berhasil kecuali ustadz sendiri memberikan contoh yang konkrit.

Keterampilan berkomunikasi guru dalam kegiatan pembelajaran mencakup 3 kemampuan pokok, sekaligus menjadi indikator dalam penelitian ini yaitu (Soeharto, n.d.):

a. Guru memiliki kemampuan untuk mengembangkan sikap positif dalam kegiatan pembelajarannya. Kemampuan ini dikonfigurasi sebagai berikut:

1) Mengenali kekuatan dan kelemahan siswa dalam kegiatan belajarnya.

2) Kami mendukung siswa untuk membangun kepercayaan diri dalam kegiatan belajar mereka.

3) Membantu orang lain memperjelas pikiran dan perasaannya agar dapat memahami dan bertukar pikiran dalam kegiatan pembelajaran

b. Kemampuan guru bersikap luwes dan terbuka dalam kegiatan pembelajaran. Kemampuan ini meliputi:

1) Sikap terbuka terhadap pendapat siswa.

2) Fleksibilitas untuk beradaptasi.

3) Menerima siswa apa adanya

4) Menunjukkan sikap peka, cepat tanggap dan perhatin terhadap perasaan kesulitan siswa pada setiap pelaksanaan dari kegiatan pembelajaran.

5) Menunjukkan sikap ramah, mengerti keadaan dan tabah terhadap siswa.

c. Kemampuan guru dalam mengelola interaksi kegiatan pembelajaran. Kemampuan ini terdiri dari:

1) Membangun hubungan yang sehat dan harmonis dalam kegiatan pembelajaran.

2) Kami menuntut agar kegiatan pembelajaran menjaga interaksi yang baik antara siswa, guru dan siswa.

3) Kuasai perilaku menyimpang yang tidak diinginkan dalam kegiatan pembelajaran (Joni, 2009).

\section{Kemampuan Guru Mengembangkan Sikap Positif Dalam Kegiatan Pembelajaran}

Komunikasi di antara guru dan siswa dalam mekanisme pembelajaran menjadi aspek penting kualitas pembelajaran. Selain itu, perilaku guru dan siswa akan menentukan proses komunikasi yang terjadi, capaian pembelajaran yang telah ditentukan, strategi yang akan diterapkan, kebijakan-kebijakan yang harus dijalankan dalam proses pembelajaran, rencana pembelajaran yang harus diimplementasikan, kesemuanya harus mampu dilakukan oleh guru untuk membangun komunikasi yang efektif dengan siswa. Proses pembelajaran di dalam kelas merupakan proses transformasi pesan edukatif berupa materi pembelajaran dari guru kepada peserta didik. Keberhasilan proses pembelajaran akan sangat tergantung kepada efektivitas proses komunikasi yang terjadi antara guru dan siswa. Adapun fungsi komunikasi guru terhadap siswa ialah sebagai berikut (Priansa, 2015) :

a. Pengendalian. Fungsi komunikasi disini sebagai controller (pengendali) pada kegiatan pembelajaran, jadi perilaku siswa dalam proses pembelajaran agar tercapainya tujuan pembelajaran dikendalikan oleh komunikasi guru tersebut.

b. Motivasi. Dalam hal ini guru memiliki peran yang strategis dalam menggunakan komunikasi sebagai fungsi motivasi dalam mencapai tujuan terhadap hal-hal yang 
dipelajari. Motivasi guru yang disampaikan dengan komunikasi yang efektiv seharusnya dapat mengembangkan siswa pada setiap proses pembelajaran.

c. Pengungkap Emosi. Dalam setiap interaksi yang terjadi ketika proses pembelajaran antara guru dan siswa pasti terjadi pengukapan emosi antar berbagai karakter siswa, oleh karenanya komunikasi berfungsi sebagai pengungkap emosi dalam rangka pemenuhan kebutuhan sosial siswa.

d. Informasi. Melalui komunikasi, guru menyampaikan seluruh informasi kepada siswa dalam proses pembelajaran, terkait materi yang dibutuhkan oleh siswa di dalam lingkungan sekolah maupun di luar.

e. Bahan Diskusi. Komunikasi berfungsi sebagai bahan diskusi, yakni menyediakan informasi yang akan digunakan oleh guru dan peserta didik dalam proses pembelajaran.

f. Sosialisasi. Komunikasi sebagai media sosialisasi antara guru dan siswa. Dalam hal ini komunikasi menyediakan dan mengajarkan tenatang pengetahuan, bagaimana bersikap sesuai dengan nilai-nilai yang ada di lingkungan sosial, serta bertindak sebagai warga sekolah yang baik.

g. Hiburan. Komunikasi berfungsi sebagai hiburan. Bahwa komunikasi merupakan media hiburan yang mudah dan murah bagi guru dan pesrta didik. Melalui komunikasi yang menghibur dan menyenangkan diharapkan siswa dan guru terlibat dalam proses pembelajaran yang menyenangkan.

h. Integrasi. Dalam hal ini komunikasi menjalankan fungsi sebagai perekat perbedaan antar karakter guru dan siswa-siswinya.

i. Pendidikan. Komunikasi mendidik dan memberikan pengetahuan yang cukup kepada guru untuk mentransfer pengetahuan dan segala kompetensi yang berhubungan dengannya, sebagai bagian dari proses pendidikan bagi siswa.

j. Kebudayaan. Melalui pendidikan dan pembelajaran yang dilaksanakan oleh guru dan siswa, maka sesungguhnya kebudayaan sedang dibangun.

Pada penelitian ini, penulis menganalisa perlu adanya kemampuan lebih dari seorang guru untuk mengembangkan sikap positif kepada siswa yang tumbuh menjadi pemuda di lingkungan masyarakat. Tentunya pembentukan karakter dari seorang guru ikut berperan dalam kehidupannya kelak. Dalam hal ini wawancara dengan guru pendidikan agama, Zubaidah (2020) mengatakan "Siswa/siswi bagi saya merupakan anak-anak yang telah matang, mengingat usia mereka yang beranjak dewasa. Tentu saja perlu ada perhatian khusus terhadap pembentukan karakter mereka. Saya sebagai seorang wali kelas selalu menanamkan pesan untuk berakhlak baik. Karena walaupun SMA ini merupakan salah satu sekolah favorit disini, namun persepsi mengenai sekolah umum dan sekolah agama masih banyak di luar sana. Bagi saya, pembentukan akhlak yang baik tergantung guru dan lingkungan mereka". Armanufianti (2020) menambahkan, "saya selalu menyelipkan pesan-pesan moral kepada siswa. Harapan saya mereka tidak hanya memiliki kecerdesan intelektual, namun juga kecerdasan emosional yang baik demi kesuksesan mereka di masa depan. Karena untuk sukses dibutuhkan karakter ataupun kepribadian yang baik".

Ahmad Taufik (2020) mengatakan "Seorang guru merupakan orang yang sangat berpengaruh terhadap anak didiknya, dan tentunya guru harus mempunyai kompetensi untuk mampu menciptakan media pembelajaran yang berkualitas yang berguna dan bermanfaat untuk 
mempermudah proses penyampaian materi dan pemahaman siswa akan materi yang disampaikan. Disamping itu yang harus betul-betul dipahami oleh seorang guru dalam berkomunikasi dengan siswa yang kurang upaya tersebut adalah, guru harus mengerti dan memahami dengan mendalam bahasa verbal dan nonverbal siswanya, supaya proses belajar mengajar berjalan secara maksimal”.

\section{Kemampuan Guru Untuk Bersikap Luwes dan Terbuka Dalam Pembelajaran}

Sikap terbuka yang ditampilkan seorang guru berpengaruh dalam proses pembelajaran di sekolah. Hal ini disebabkan karena guru adalah orang yang bertanggungjawab terhadap perkembangan anak didik dengan mengupayakan seluruh potensinya, baik potensi kognitif, afektif, dan psikomotorik. Selain itu juga guru bertanggungjawab dalam memberikan pertolongan pada anak didik dalam perkembangan jasmani dan rohaninya agar mencapai kedewasaan, serta mampu dalam memenuhi tugasnya sebagai hamba Allah SWT (Nasor, 2014).

Peneliti melakukan wawancara kepada guru pendidikan agama yang mengajar kelas terkait sikap luwes dan terbuka yang diberikan oleh guru kepada siswa. Pernyataan Zubaidah (2020) bahwa "untuk membentuk karakter yang baik pada siswa, khususnya siswa kelas XII. Guru harus benar-benar memahami keadaan siswa tersebut. Guru harus memberikan perhatian lebih kepada siswa yang agak bandel supaya mau memperbaiki karakter mereka. Karena bagi saya, guru memiliki peran penting dalam hal ini setelah orang tua siswa tentunya. Faktor lingkungan yang juga mempengaruhi perlu diberi pemahaman kepada mereka agar bisa memilih lingkungan yang baik dan kurang baik". Leny Neliwati (2020) menambahkan"untuk menjadi guru yang disenangi siswa, saya selalu menjalin kedekatan dan sikap yang luwes ketika memberikan pesan moral kepada siswa. Karena saya yakin, dengan karakter yang luwes dan menyenangkan, siswa akan menyukai dan akan mengikuti perkataan yang disampaikan. Namun saya tetap memperhatikan moral dan etika mereka terhadap saya".

Dari hasil wawancara di atas terlihat bahwa selama ini guru agama di SMAN 1 Bangko telah banyak memberikan pengajaran mengenai pembentukan karakter siswa dengan memberikan sikap yang terbuka sehingga tercipta suasana komunikasi yang menyenangkan. Karakter seseorang dapat dilihat dari perilakunya dalam pendidikan yang diterimanya. Oleh karena itu, pendidikan harus dikemas dalam dua cara: bahan ajar dan manajemen agar terbentuk karakter yang baik, dan seseorang dapat berperilaku baik. Agar pendidikan dapat diterima secara utuh, diperlukan suatu media yang tepat untuk menyampaikan segala pesannya, termasuk nilai-nilai pendidikan, dan merupakan media komunikasi.

Mengutip komentar F.W. Foerster, Sutarjo Adisusilo mengatakan bahwa karakter adalah yang mendefinisikan seseorang. Karakter dapat diidentifikasi dan melampaui pengalaman kontingen dari sifat-sifat yang terus berubah dengan sifat-sifat yang tetap. Dengan demikian, karakter adalah seperangkat nilai yang telah menjadi kebiasaan hidup, dan karenanya menjadi ciri permanen seseorang. Misalnya, kerja keras, pantang menyerah, kejujuran, kesederhanaan, dan lain-lain (Adisusilo, 2017). Mengutip pendapat Alwisol, karakter dimaknai sebagai penjelasan tentang perilaku yang menekankan nilai baik dan buruk, baik dan buruk, baik tersurat maupun tersirat. Kepribadian berbeda dengan kepribadian karena konsep kepribadian bebas dari nilai. Meskipun demikian, baik kepribadian maupun kepribadian menunjukkan perilaku yang tampak dalam lingkungan sosial (Arismantoro, 2008). Menurut Ngainun Naim, karakter adalah seperangkat sikap, perilaku, motivasi, dan keterampilan. Kepribiadian atau karakter adalah sikap 
yang sama dengan keinginan untuk melakukan yang terbaik, kemampuan intelektual seperti sikap kritis dan alasan moral, perilaku seperti kejujuran dan tanggung jawab, kemampuan untuk mempertahankan prinsip-prinsip moral dalam situasi yang tidak benar, orang-orang dalam masyarakat termasuk keterampilan interpersonal dan emosional yang memungkinkan berinteraksi secara efektif di dalam janji kontribusi untuk berbagai situasi, komunitas dan orang-orangnya (Naim, 2012).

Dengan menggunakan berbagai definisi seperti diuraikan di atas, dapat diketahui bahwa memaknai karakter adalah dengan definisi rangkaian sikap, perilaku, motif, dan teknik seseorang yang dibentuk oleh internalisasi pribadi yang kemudian menjadi cara pandang, pemikiran, tindakan dan landasan tindakan untuk hidup dan bekerja sama dalam keluarga, masyarakat, bangsa dan bangsa.

\section{Kemampuan Guru Untuk Mengelola Interaksi dalam Kegiatan Pembelajaran}

Demi tercapainya siswa/siswi yang berkarakter positif. Peran guru agama di sekolah sebagai orang tua harus sangat diperhatikan. Bidang studi pendidikan agama merupakan sokoguru (tiang/penegak) yang paling potensial dalam membina generasi muda yang baik. Guru agama di sekolah sangatlah penting untuk mengarahkan siswanya kepada hal-hal yang baik dan lebih mengetahui anjuran agama Islam yang sebenarnya (Dakwah et al., 2017a). Kemampuan berkomunikasi dan menjalin hubungan yang baik dengan siswa akan menentukan keberhasilan guru dalam membentuk karakter siswa. Peneliti melakukan wawancara dengan Azni Yandriati (2020) mengenai cara yang dilakukan untuk membentuk karakter siswa salah satunya dengan memberikan perhatian terhadap prestasi yang dicapai. "Saya selalu mengapresiasi siswa yang berprestasi dalam pelajaran maupun ekstrakurikuler. Hal ini penting menurut saya untuk menjaga semangat serta menumbuhkan kepercayaan diri untuk terus mengasah kemampuan mereka. Saya berkomunikasi secara personal dengan mereka untuk memberikan motivasi-motivasi”. Hal senada diungkapkan oleh Darmawati (2020), "untuk membentuk karakter siswa, guru perlu memberikan contoh yang baik. Sikap dan perilaku Guru sebagai panutan bagi siswa merupakan cerminan terhadap siswa. Ada beberapa guru yang menjadi favorit bagi siswa, ketika siswa telah memiliki kedekatan dengan siswa maka akan memudahkan guru untuk berinteraksi secara spontan dengan siswa". Guru harus menjadi teladan dalam membentuk karakter peserta didik baik di dalam kelas ketika proses belajar mengajar (Asiah, 2020).

Kemampuan guru dalam berinteraksi akan memungkinkan tercapainya tujuan komunikasi untuk membentuk karakter siswa. Dengan berkomunikasi secara meyakinkan maka siswa akan percaya kepada guru. Ahmad Taufik (2020) mengatakan, "bagi saya, komunikasi guru yang terpenting demi kemajuan siswanya. Guru yang mahir dalam mempengaruhi siswa akan lebih berpotensi untuk mewujudkan siswa yang baik. Guru memiliki kuasa atas siswa, jadi ketika siswa tidak mau mengikuti arahan dari guru, maka guru boleh memberikan sanksi. Dan saya rasa ini juga menyangkut pembentukan karakter siswa itu sendiri". "Tidak selamanya guru dapat disalahkan, karena waktu kebersamaan guru dengan siswa tidak begitu lama. Hanya selama berlangsungnya proses belajar. Jadi menurut saya walaupun guru berperan dalam pembentukan karakter siswa, namun ketika siswa itu bertindak tidak wajar maka perlu ditelusuri lagi faktor lainnya. Namun selama ini menurut saya guru selalu berusaha keras untuk menjadikan siswa/siswi SMAN 1 
Bangko sebagai pemuda yang baik di masyarakat, tentu kami juga sangat berharap dukungan orang tua" (Zubaidah, 2020).

Pencerahan dan pembentukan ketangguhan karakter dianggap perlu dan penting bagi sekolah dan pemangku kepentingannya untuk menjadi pijakan dalam menyelenggarakan pendidikan kepribadian dan karakter di sekolah. Tujuan pendidikan karakter pada dasarnya adalah untuk membina dan mencerahkan siswa dengan ketangguhan yang baik yang memungkinkan mereka untuk melakukan yang terbaik untuk menormalkan segala sesuatu dan tumbuh dengan kemampuan untuk memiliki tujuan hidup dan mempromosikan kelahiran anak-anak yang baik. Masyarakat juga berperan dalam membentuk kepribadian anak melalui orang tua dan lingkungan (Warsita, 2008). Kepribadian seorang siswa berkembang dalam beberapa tahap. Tahap kebiasaan (habit) dengan pengetahuan (knowing) dan eksekusi (actuating) (Tu'u, 2004).

Karakter tidak terbatas pada pengetahuan. Kecuali seseorang dengan pengetahuan tertentu dilatih (dibiasakan) untuk berbuat baik, dia tidak dapat selalu bertindak berdasarkan pengetahuannya. Kepribadian juga mencapai alam emosi dan kebiasaan seseorang. Dengan demikian dibutuhkan tiga unsur karakter yang baik (components of good character), yaitu:

a. Pengetahuan tentang moral (moral knowing)

Dimensi pengetahuan moral yang akan mengisi ranah kognitif adalah kesadaran moral, pengetahuan nilai moral (knowing moral values), pengambilan perspektif, penalaran moral, dan pengetahuan diri.

b. Perasaan/penguatan emosi (moral feeling)

Moral feeling merupakan pemantapan dan peningkatan sisi emosi pelajar yang bertujuan membentuk pribadi menjadi sosok berkarakter. Pelajar dituntut agar dapat merasakan pola dan bentuk tertentu dari sikap dan tindakan, yaitu kesadaran akan jati diri (conscience), percaya diri (self esteem), kepekaan terhadap derita orang lain (emphaty), cinta kebenaran (loving the good), pengendalian diri (self control), dan kerendahan hati (humility).

c. Perbuatan bermoral (moral action)

Moral action adalah hasil dari dua unsur karakter lainnya. Agar dapat dipahami dari apa yang memberikan stimulus seseorang melakukan perbuatan yang baik (act morally) maka harus diperhatikan dan diamati tiga unsur lain dari sikap kepribadian, yaitu kompetensi (competence), keinginan (will), dan kebiasaan (habit) (Adisusilo, 2017).

Dari beberapa hasil wawancara di atas, maka dapat peneliti analisa bahwa guru agama SMAN 1 Bangko telah melakukan upaya dalam membentuk karakter siswa dengan menerapkan segala macam kemampuan yang dimiliki. Hal ini dilakukan berdasarkan keharusan dan kemampuan guru dalam berkomunikasi dengan siswanya. Tanpa komunikasi yang baik maka semua pesan yang disampaikan tidak akan dapat diterima oleh siswa.

\section{KESIMPULAN}

Dari hasil penelitian ini maka dapat disimpulkan bahwa keberhasilan guru agama dalam membentuk karakter siswa di SMAN 1 Bangko tergantung pada kemampuan guru dalam mengembangkan sikap positif dalam kegiatan pembelajaran. Guru agama telah melakukan komunikasi kepada siswa dalam segala kegiatan pembelajaran, membantu menumbuhkan rasa percaya diri pada siswa, serta membantu memperjelas pikiran dan perasaan siswa sehingga mudah untuk menerima pesan dari guru dalam membentuk karakter siswa. Kemampuan guru agama 
SMAN 1 Bangko untuk bersikap luwes terbuka dalam kegiatan pembelajaran juga telah ditunjukkan oleh guru dengan bersikap terbuka, menerima keadaan siswa, menunjukkan sikap sensitif, responsif, dan ramah tamah serta sabar terhadap siswa SMAN 1 Bangko. Dan guru agama SMAN 1 Bangko juga telah menunjukkan kemampuan mengelola interaksi dalam kegiatan pembelajaran dalam pembentukan karakter siswa SMAN 1 Bangko dengan memberikan penyadaran mengenai hubungan yang baik dengan guru maupun antarsiswa, serta pemberian hukuman atau sanksi dalam rangka pembelajaran akan kesadaran melakukan penyimpangan.

\section{DAFTAR PUSTAKA}

Adisusilo, S. (2017). Pembelajaran Nilai Karakter. Raja Grafindo Persada.

Ainiyah, N., \& Wibawa, N. H. H. P. (2013). Pembentukan Karakter Melalui Pendidikan Agama Islam. Al-Ulum, 13(1), 25-38.

Arismantoro. (2008). Character Building. Tiara Wacana.

Asiah, N. (2020). School Management in the Implementation of Character Values in the TeachingLearning Process. 1st Progress in Social Science, Humanities and Education Research Symposium (PSSHERS 2019), 645-648.

Dakwah, F., Ilmu, D. A. N., Islam, U., \& Raden, N. (2017a). Pola Komunikasi Guru Agama Dalam Membina Akhlak Siswa Smk Al-Huda.

Dakwah, F., Ilmu, D. A. N., Islam, U., \& Raden, N. (2017b). POLA KOMUNIKASI GURU AGAMA DALAM MEMBINA AKHLAK SISWA SMK AL-HUDA.

Danim, S. (2002). Menjadi Peneliti Kualitatif. Pustaka Setia.

Elisah, J. dan. (2011). Implementasi Pendidikan Karakter dalam Pembelajaran. Prestasi Pustaka.

Joni, R. (2009). Filsafat Komunikasi. Graha Ilmu.

Kanan, K. W. A. Y. (2017). Pola Komunikasi Guru Dalam Pembinaan Akhlak Siswa Smk Al-Fajar Fakultas Dakwah Dan Ilmu Komunikasi Universitas Islam Negeri ( Uin ) Raden Intan Lampung 1438 H / 2017 M Pola Komunikasi Guru Dalam Pembinaan Akhlak Siswa Smk AlFajar.

Naim, N. (2012). Character building : optimalisasi peran pendidikan dalam pengembangan ilmu \& pembentukan karakter bangsa. Ar-Ruzz Media.

Nasor, M. (2014). Direktur PPs IAIN Raden Intan Lampung. Komunikasi Guru Dan Siswa Dalam Peningkatan Prestasi Siswa, 7, 149-166.

Onong Uchjana Effendy. (2007). Ilmu Komunikasi Teori dan Praktek. Rosdakarya.

Priansa, E. K. dan D. J. (2015). Manajemen Kelas. Alfabeta.

Putra, H. R. (2021). Strategi Komunikasi Politik Partai Aceh Dalam Menarik Simpati Masyarakat. $2,180-192$.

Soeharto, K. (n.d.). Teknologi Pembelajaran (Pendekatan System, Konsepsi, dan Model, SAP, Evaluasi, Sumber Belajar Media). Surabaya Intelectual Club.

Tarmizi. (2000). Komunikasi Guru Agama dalam Membentuk Karakter Siswa/I Di SMPN 02 Rambah Hilir. 
Tu’u, T. (2004). Peran Disiplin Pada Perilaku dan Prestasi Siswa. Gratisindo.

Warsita, B. (2008). Teknologi Pembelajaran; Landasan \& Aplikasinya. Rhineka Cipta.

Zakaria, Z. (2021). Strategi Komunikasi Guru Pendidikan Agama Dalam Membentuk Akhlak Mulia Peserta Didik Di Madrasah Tsanawiyah. JIKAP PGSD: Jurnal Ilmiah Ilmu Kependidikan, 5(2), 344. https://doi.org/10.26858/jkp.v5i2.20356 